\title{
Article \\ Effect of Manure from Cattle Fed 3-Nitrooxypropanol on Anthropogenic Greenhouse Gas Emissions Depends on Soil Type
}

\author{
Tien L. Weber ${ }^{1,2} \mathbb{D}$, Xiying Hao ${ }^{2}$, Cole D. Gross ${ }^{1} \mathbb{D}$, Karen A. Beauchemin ${ }^{2} \mathbb{D}$ and Scott X. Chang ${ }^{1, * \mathbb{D}}$ \\ 1 Department of Renewable Resources, Faculty of Agricultural, Life and Environmental Sciences, \\ University of Alberta, 442 Earth Sciences Building, Edmonton, AB T6G 2E3, Canada; \\ tlweber@ualberta.ca (T.L.W.); cgross@ualberta.ca (C.D.G.) \\ 2 Agriculture and Agri-Food Canada, Lethbridge Research and Development Centre, 5403 1st Ave S., \\ Lethbridge, AB T1J 4B1, Canada; xiying.hao@canada.ca (X.H.); karen.beauchemin@canada.ca (K.A.B.) \\ * Correspondence: sxchang@ualberta.ca; Tel.: 1-780-492-6375
}

Citation: Weber, T.L.; Hao, X.; Gross, C.D.; Beauchemin, K.A.; Chang, S.X. Effect of Manure from Cattle Fed 3-Nitrooxypropanol on Anthropogenic Greenhouse Gas Emissions Depends on Soil Type. Agronomy 2021, 11, 371. https:// doi.org/10.3390/agronomy11020371

Academic Editor: José L. S. Pereira

Received: 31 December 2020

Accepted: 16 February 2021

Published: 20 February 2021

Publisher's Note: MDPI stays neutral with regard to jurisdictional claims in published maps and institutional affiliations.

Copyright: (c) 2021 by the authors Licensee MDPI, Basel, Switzerland. This article is an open access article distributed under the terms and conditions of the Creative Commons Attribution (CC BY) license (https:// creativecommons.org/licenses/by/ $4.0 /)$

\begin{abstract}
Cattle production is a large source of greenhouse gas (GHG) emissions from the Canadian livestock sector. Efforts to reduce $\mathrm{CH}_{4}$ emissions from enteric fermentation have led to modifications of diet composition for livestock, resulting in a corresponding change in manure properties. We studied the effect of applying manure from cattle fed a barley-based diet with and without the methane inhibitor supplement, 3-nitrooxypropanol (3-NOP), on soil GHG emissions. Three soils common to Alberta, Canada, were used: a Black Chernozem, a Dark Brown Chernozem, and a Gray Luvisol. We compared the supplemented (3-NOPM) and non-supplemented manure (BM) amendments to a composted 3-NOPM (3-NOPC) amendment and a control with no manure amendment (CK). In an 84day laboratory incubation experiment, 3-NOPM had significantly lower cumulative $\mathrm{CO}_{2}$ emissions compared to BM in both the Black Chernozem and Gray Luvisol. The cumulative $\mathrm{N}_{2} \mathrm{O}$ emissions were lowest for 3-NOPC and CK and highest for 3-NOPM across all soil types. Cumulative $\mathrm{CH}_{4}$ emissions were only affected by soil type, with a net positive flux from the fine-textured Gray Luvisol and Dark Brown Chernozem and a net negative flux from the coarse-textured Black Chernozem. Cumulative anthropogenic GHG emissions ( $\mathrm{CO}_{2}$-equivalent) from soil amended with 3-NOPM were significantly higher than those for both BM and CK amendments in the Black Chernozem, while the cumulative anthropogenic GHG emissions from the 3-NOPC treatment were similar to or significantly lower than those for the BM and CK treatments across all soil types. We conclude that soil GHG emissions resulting from the 3-NOPM amendment are dependent on soil type and 3-NOPM could potentially increase soil GHG emissions compared to BM or CK. Although we show that the composting of 3-NOPM prior to soil application can reduce soil GHG emissions, the composting process also releases GHGs, which should also be considered in assessing the life-cycle of manure application. Our results provide a first look at the potential effect of the next stage in the life cycle of 3-NOP on GHG emissions. Further research related to the effect of soil properties, particularly in field studies, is needed to assess the best management practices related to the use of manure from cattle-fed diets supplemented with 3-NOP as a soil amendment.
\end{abstract}

Keywords: cattle manure; Chernozemic soil; diet; enteric fermentation; greenhouse gas; inhibitor

\section{Introduction}

Emissions of greenhouse gases (GHGs) are a growing concern due to the effect of GHGs on the global climate. Cattle production releases 2-7 times more GHGs, mainly in the form of methane $\left(\mathrm{CH}_{4}\right)$ emissions from enteric fermentation, than the production of any other livestock [1]. Methane has 28 times the greenhouse effect of carbon dioxide $\left(\mathrm{CO}_{2}\right)$ when evaluated on a 100-year time scale; as such, reducing $\mathrm{CH}_{4}$ emissions is essential for environmental sustainability $[2,3]$. To reduce the $\mathrm{CH}_{4}$ emissions from livestock production 
systems, recent research has focused on feeding management practices. such as the use of feed additives and changing the composition of feed to alter microbial compositions and activities during enteric fermentation.

The use of feed additives or changes in feed composition may alter the properties of cattle manure, which could affect soil GHG emissions when the manure is applied to the land $[4,5]$. While manure from cattle feedlots may pose many environmental problems, such as eutrophication and acidification, using manure as an organic amendment is important to improve soil fertility [1,6-8]. Cattle manure amendment increases soil aggregation, water holding capacity, and microbial activities [7]. However, little research has been conducted to understand the effect of manure from cattle fed with additives or different feed compositions on GHG emissions when such manure is applied to the land.

One of the feed additives to help mitigate $\mathrm{CH}_{4}$ emissions from enteric fermentation in ruminant livestock is 3-nitrooxypropanol (3-NOP) [9,10]. The 3-NOP inhibits the activity of methyl coenzyme-M reductase, the enzyme that catalyzes the last step in $\mathrm{CH}_{4}$ production. By substituting a reducible nitrate $\left(\mathrm{NO}_{3}{ }^{-}\right)$group in place of a nickel (Ni) ion, 3-NOP inactivates the methyl coenzyme-M reductase by oxidizing its active sites [11]. The use of 3-NOP does not reduce the abundance of bacteria, protozoa, and methanogens, but rather alters the function of specific microorganisms, resulting in a reduction in $\mathrm{CH}_{4}$ formation and a shift in the volatile fatty acid fermentation profile [12]. Earlier research has shown that 3-NOP can reduce enteric $\mathrm{CH}_{4}$ emissions by up to 28-33\% [5,13] and increase milk production due to a $2-12 \%$ reduction in potential energy loss from $\mathrm{CH}_{4}$ production $[4,5,14]$. However, it is not clear how the addition of 3-NOP in the feed will affect soil GHG emissions when the cattle manure is applied as an organic amendment to various soil types.

Another way to reduce GHG emissions is by altering livestock manure management practices, such as composting, designed to transform biologically active components in manure into less degradable forms [15]. The composting of manure helps reduce the odor and the volume of manure that needs to be transported for land application [15-18]. Up to $70 \%$ of the mass of fresh manure is water, making the volume to be transported excessively large if fresh manure is used as an organic fertilizer [16]. Composting can even help reduce pathogens, parasites, and weed seeds that come with the manure $[15,19,20]$. The process of composting manure converts easily degradable $\mathrm{C}$ and $\mathrm{N}$ into less biologically active forms, and the resulting manure has lower $\mathrm{pH}$, labile organic matter, $\mathrm{C} / \mathrm{N}$ ratio, and GHG emissions [15]. During the composting process, the rate of mineralization decreases as easily degradable materials are converted to $\mathrm{CO}_{2}$ [15]. In addition, improving aeration during composting can change $\mathrm{C}$ and $\mathrm{N}$ dynamics and alter GHG emissions [20]. The soil application of composted manure originating from cows fed wheat dried distillers' grains with solubles has been reported to significantly lower GHG emissions [6]. However, some composted manure from cattle fed with feed additives have a greater risk for $\mathrm{N}$ loss due to the additional $\mathrm{N}$ that comes with the additives [21]. As far as we know, the effect of composted manure from cattle fed with 3-NOP on soil GHG emissions has not been studied.

Manure is often applied to different soil types to improve sustainable management operations [10]. Given the potential importance of 3-NOP in reducing enteric $\mathrm{CH}_{4}$ emissions, we aimed to (i) understand how manure from cattle fed with 3-NOP-supplemented diets affects soil GHG emissions when used as an amendment; (ii) determine if the resulting GHG emissions could be reduced via composting the 3-NOP-manure prior to soil application; and (iii) assess the effect of soil type on the resulting GHG emissions. By studying the impact of the 3-NOP supplement in cattle diets on GHG emissions when the resulting manure is used as a soil amendment, we hope to provide a first look at the potential effect of the next stage in the life cycle of 3-NOP. 


\section{Materials and Methods}

\subsection{Experimental Design and Treatments}

The experiment used a completely randomized design (CRD) based on a $3 \times 4$ factorial experiment with three soil types and four manure treatments. The treatments were replicated four times. Properties of the soils and manure amendments used in the study are presented in Table 1.

Table 1. Initial chemical properties (means \pm SE) of soil and manure samples used in the laboratory incubation experiment $(n=3)$.

\begin{tabular}{|c|c|c|c|c|c|c|c|}
\hline Parameter & $\mathrm{pH}^{+}$ & $\begin{array}{c}\text { Total } \\
\text { Nitrogen }\end{array}$ & $\begin{array}{l}\text { Organic } \\
\text { Carbon }\end{array}$ & $\mathrm{C} / \mathrm{N}$ & $\mathrm{NH}_{4}{ }^{+}-\mathrm{N}$ & $\mathrm{NO}_{3}{ }^{-}-\mathrm{N}$ & AN \\
\hline & & \multicolumn{2}{|c|}{$\left(\mathrm{g} \mathrm{kg}^{-1}\right)$} & ratio & \multicolumn{3}{|c|}{$\left(\mathrm{mg} \mathrm{kg}^{-1}\right)$} \\
\hline \multicolumn{8}{|l|}{ Manure type } \\
\hline $\mathrm{BM}$ & $7.39 \pm 0.05^{\mathrm{a}}$ & $10.4 \pm 0.21^{b}$ & $100 \pm 2.13^{a}$ & $9.58 \pm 0.02^{a}$ & $7.53 \pm 1.04^{\mathrm{a}}$ & $635 \pm 13.0^{b}$ & $643 \pm 19.4^{\mathrm{a}}$ \\
\hline 3-NOPM & $7.09 \pm 0.02^{b}$ & $12.8 \pm 0.51^{\mathrm{a}}$ & $114 \pm 4.09^{b}$ & $8.89 \pm 0.09^{b}$ & $10.9 \pm 1.04^{\mathrm{a}}$ & $1098 \pm 32.0^{\mathrm{a}}$ & $1109 \pm 30.7^{b}$ \\
\hline 3-NOPC & $6.99 \pm 0.03^{c}$ & $9.62 \pm 0.08^{b}$ & $85.1 \pm 2.25^{c}$ & $8.84 \pm 0.17^{b}$ & $11.9 \pm 0.60^{a}$ & $1056 \pm 16.2^{\mathrm{a}}$ & $1068 \pm 22.0^{b}$ \\
\hline \multicolumn{8}{|l|}{ Soil type } \\
\hline BLC & $7.25 \pm 0.06^{\mathrm{a}}$ & $2.44 \pm 0.39^{a}$ & $23.0 \pm 4.12^{\mathrm{a}}$ & $9.36 \pm 0.35^{b}$ & $4.02 \pm 0.47^{b}$ & $49.2 \pm 2.31^{\mathrm{a}}$ & $35.9 \pm 1.48^{b}$ \\
\hline GL & $3.91 \pm 0.04^{b}$ & $0.98 \pm 0.14^{b}$ & $12.2 \pm 2.53^{\mathrm{a}}$ & $12.0 \pm 1.05^{\mathrm{a}}$ & $6.47 \pm 0.23^{\mathrm{a}}$ & $32.7 \pm 1.15^{b}$ & $55.0 \pm 1.43^{c}$ \\
\hline DBC & $7.31 \pm 0.03^{\mathrm{a}}$ & $1.97 \pm 0.29 \mathrm{ab}$ & $22.0 \pm 4.39^{\mathrm{a}}$ & $14.3 \pm 0.13^{a}$ & $3.00 \pm 0.33^{b}$ & $6.45 \pm 0.02^{\mathrm{c}}$ & $9.03 \pm 0.45^{\mathrm{a}}$ \\
\hline
\end{tabular}

Note: Manure type: BM, barley-based manure; 3-NOPM, manure from cows fed 3-NOP supplement; 3-NOPC, composted manure from cows fed 3-NOP supplements. BLC, Black Chernozem; GL, Gray Luvisol; DBC, Dark Brown Chernozem. ${ }^{\dagger}$ Soil $\mathrm{pH}$ was measured in an 1:5 soil:water (v:v) ratio. Abbreviations: $\mathrm{C} / \mathrm{N}$, soil carbon to nitrogen ratio; $\mathrm{AN}$, Sum of $\mathrm{NH}_{4}{ }^{+}-\mathrm{N}$ and $\mathrm{NO}_{3}{ }^{-}-\mathrm{N}$. Means followed by a common letter within a column are not significantly different $(p<0.05)$.

Surface soil samples $(0-15 \mathrm{~cm})$ used in this incubation experiment were collected in late spring 2017. Soil types collected include: (i) a Black Chernozem (BLC) from a prairie in Virden, Manitoba, with a sandy loam texture; (ii) a Gray Luvisol (GL) from a cereal-canola field in Beaverlodge, Alberta, with a clay loam texture, and (iii) a Dark Brown Chernozem (DBC) from an alfalfa/grass field in Lethbridge, Alberta, with a clay loam texture.

The manures were generated from a 238-d feeding trial at Agriculture and Agri-Food Canada's Lethbridge Research and Development Center as reported in Vyas et al. [10]. Soils were amended at $160 \mathrm{Mg} \mathrm{ha}^{-1}$ with (i) stockpiled manure from cattle fed a traditional barley-based diet (BM); manure from cattle fed a barley-based diet supplemented with 3NOP (at $200 \mathrm{mg} \mathrm{kg}^{-1}$ dry matter for the initial 105-d backgrounding phase and $125 \mathrm{mg} \mathrm{kg}^{-1}$ dry matter for the final 133-d finishing phase) which was (ii) stockpiled (3-NOPM) or (iii) composted (3-NOPC) in open-air windrows following the method described in Larney and Hao [15]; and (iv) a control (CK, soil without manure addition).

\subsection{Soil Incubation}

After collection from the field, the soils were shipped to the University of Alberta laboratory for incubation. All soil types were air-dried at room temperature, passed through a 2-mm sieve to remove debris and coarse fragments, homogenized and stored at room temperature [22]. Before setting up the incubation experiment, soil samples were dried at $105{ }^{\circ} \mathrm{C}$ for $48 \mathrm{~h}$ to determine soil water content. The water-filled pore space (WFPS) was then calculated by:

$$
\% \text { WFPS }=(\mathrm{SWC} \times \mathrm{BD}) /(1-(\mathrm{BD} / \mathrm{PD})),
$$

where SWC is the soil water content $\left(\mathrm{g} \mathrm{H}_{2} \mathrm{O} \mathrm{g}{ }^{-1}\right.$ dry soil), BD is bulk density $\left(\mathrm{Mg} \mathrm{m}^{-3}\right)$, and $\mathrm{PD}$ is particle density $\left(2.65 \mathrm{Mg} \mathrm{m}^{-3}\right)[23,24]$.

The incubation experiment was conducted in a Forma Diurnal Growth ChamberModel 3740 (Thermo Fisher Scientific, Waltham, MA, USA) at $25^{\circ} \mathrm{C}$. In setting up the laboratory incubation experiment, $200 \mathrm{~g}$ (dry-weight basis) of soil was weighed and placed 
into one of the 48 (four manure treatments $x$ three soil types $x$ four replications) 1-L Mason jars. The \% WFPS of the soil was adjusted to $60 \%$ using a $20 \mathrm{~mL}$ syringe to distribute deionized water evenly over the surface of the soil, then a piece of aluminum foil with four small pinholes was used to cover the jar to minimize water loss but allow gas exchange [25]. The samples were pre-incubated in the incubation chamber for seven days.

Immediately after the pre-incubation, $16.6 \mathrm{~g}$ of manure (dry-weight basis) was mixed into each Mason jar based on a pre-determined treatment distribution, with CK remaining unamended. This amount is comparable to a common rate of field application of $160 \mathrm{Mg} \mathrm{ha}{ }^{-1}$ of the organic amendment, typical for barley forage production [6]. The $60 \%$ WFPS was maintained by adjusting the soil water content weekly using a syringe for the first two weeks and was then the soils were adjusted to 80\% WFPS for the remainder of the 84-d incubation; the increase in WFPS was made to better understand the response of anaerobic microbial processes [26].

\subsection{Gas Sampling}

The fluxes of GHGs of $\mathrm{CO}_{2}$, nitrous oxide $\left(\mathrm{N}_{2} \mathrm{O}\right)$, and $\mathrm{CH}_{4}$ were measured on days 1 , $4,7,14,21,35,38,42,49,63$, and 84 of the incubation. During each sampling, gas samples were collected twice by first sealing each Mason jar with a lid containing a butyl rubber stopper. The first gas sample was collected with a $20 \mathrm{~mL}$ syringe immediately after the closure of the Mason jar (time 0) and transferred to a pre-evacuated $12 \mathrm{~mL}$ exetainer. After $24 \mathrm{~h}$ of closure, another gas sample was collected in the same manner, and the butyl rubber stoppers were replaced with the aluminum foil described above to allow air exchange between the Mason jar and the atmosphere to occur. A Varian CP-3800 gas chromatograph (Varian, Palo Alto, CA, USA), equipped with a thermal conductivity detector (TCD), a flame ionization detector (FID), and an electron capture detector (ECD), was used to measure the $\mathrm{CO}_{2}, \mathrm{CH}_{4}$, and $\mathrm{N}_{2} \mathrm{O}$ concentrations, respectively, in the gas samples.

The $\mathrm{CO}_{2}, \mathrm{~N}_{2} \mathrm{O}$, and $\mathrm{CH}_{4}$ fluxes, in units of $\mathrm{mg} \mathrm{CO}-\mathrm{C} \mathrm{kg}_{2}^{-1} \mathrm{~h}^{-1}, \mu \mathrm{g} \mathrm{N} \mathrm{N}_{2} \mathrm{O}-\mathrm{N} \mathrm{kg}{ }^{-1} \mathrm{~h}^{-1}$, and $\mu \mathrm{g} \mathrm{CH} \mathrm{CH}_{4}-\mathrm{C} \mathrm{kg}^{-1} \mathrm{~h}^{-1}$, respectively, were calculated using the following equation [6]:

$$
\mathrm{F}=(\rho * \Delta \mathrm{c} * \mathrm{~V} * 273) /(\mathrm{W} * \Delta \mathrm{t} *(273+\mathrm{T})),
$$

where:

$\rho=$ air density at standard state;

$\Delta \mathrm{c}=$ change in concentration (ppbv) between sampling intervals;

$\Delta \mathrm{t}=$ sampling interval $(24 \mathrm{~h})$;

$\mathrm{W}=$ soil mass $(200 \mathrm{~g})$;

$\mathrm{V}=$ headspace volume in the Mason jar;

$\mathrm{T}=$ incubation temperature $\left(25^{\circ} \mathrm{C}\right)$.

Dissolved $\mathrm{N}_{2} \mathrm{O}$ was calculated according to Moraghan and Buresh [27] and added to the measured $\mathrm{N}_{2} \mathrm{O}$ flux to determine the total $\mathrm{N}_{2} \mathrm{O}$ flux. Total $\mathrm{CO}_{2}$ and $\mathrm{CH}_{4}$ fluxes were determined by measured $\mathrm{CO}_{2}$ and $\mathrm{CH}_{4}$ fluxes only. Cumulative GHG emissions were calculated by summing gas fluxes over the $84 \mathrm{~d}$ incubation period. The $\mathrm{CO}_{2}$-eq GHG emissions were calculated using the GWP coefficients of 265 and 28 for $\mathrm{N}_{2} \mathrm{O}$ and $\mathrm{CH}_{4}$, respectively, over a 100-year time frame based on the amount of mass of a gas is emitted [3].

\subsection{Physical and Chemical Analyses}

To analyze for total $\mathrm{C}$ and $\mathrm{N}$, samples were dried at $70{ }^{\circ} \mathrm{C}$ and ground with a mortar and pestle and analyzed using a dry combustion technique with an automated $\mathrm{CN}$ analyzer (Carlo Erba, Milan, Italy). Soil pH was analyzed on a suspension using a 1:5 soil weight to deionized water volume ratio with an Orion $\mathrm{pH}$ meter (Thermo Fisher Scientific, Waltham, $\mathrm{MA}, \mathrm{USA}$ ). For soils with a $\mathrm{pH}>7.2$, the inorganic $\mathrm{C}$ was removed by treating the soil with $6 \mathrm{M}$ of $\mathrm{HCl}$ prior to the determination of SOC content $[28,29]$.

To measure the available $\mathrm{N}\left(\mathrm{NO}_{3}{ }^{-}-\mathrm{N}\right.$ and $\left.\mathrm{NH}_{4}{ }^{+}-\mathrm{N}\right)$, the samples were extracted with $0.5 \mathrm{M} \mathrm{K}_{2} \mathrm{SO}_{4}$ solutions at a 1:5 (w:v) soil to extract ratio; the mixture was shaken at $250 \mathrm{rpm}$ on a mechanical shaker for $1 \mathrm{~h}$ then filtered using Whatman No. 42 filter paper [30]. 
Nitrate- and $\mathrm{NH}_{4}{ }^{+}-\mathrm{N}$ were determined colorimetrically using vanadium (III) in acid and indophenol blue methods, respectively $[30,31]$.

\subsection{Statistical Analysis}

All the statistical analyses were performed using R v.1.1 (R Core Team, 2020) with statistical significance set at $\alpha=0.05$ for all tests. Two-way analysis of variance (ANOVA) was used to analyze the effect of soil type, manure type, and their interaction on cumulative GHG emissions and soil properties in the laboratory incubation experiment [32]. The normality of distribution and the homogeneity of variance of the data were checked with the Shapiro and Bartlett tests. Non-homogeneous data of anthropogenic GHG emissions, $\mathrm{CH}_{4}$ emissions $\mathrm{N}_{2} \mathrm{O}$ emissions $\mathrm{NH}_{4}{ }^{+}-\mathrm{N}$, and $\mathrm{C} / \mathrm{N}$ ratio were transformed with first-order auto-regression. Cumulative GHG emissions and initial properties were analyzed using a Tukey-Kramer test. Relationships between the initial properties and cumulative GHG emissions were examined using Spearman's rank correlation.

\section{Results and Discussion}

\section{1. $\mathrm{CO}_{2}$ Emissions}

There was an initial peak in $\mathrm{CO}_{2}$ emissions in all soils (Figure 1a) from the addition of cattle manure at the beginning of the incubation, likely due to the improved availability of the substrate that stimulated microbial activity and microorganisms from the manure, contributing to an increase in SOM decomposition $[7,18,19]$.
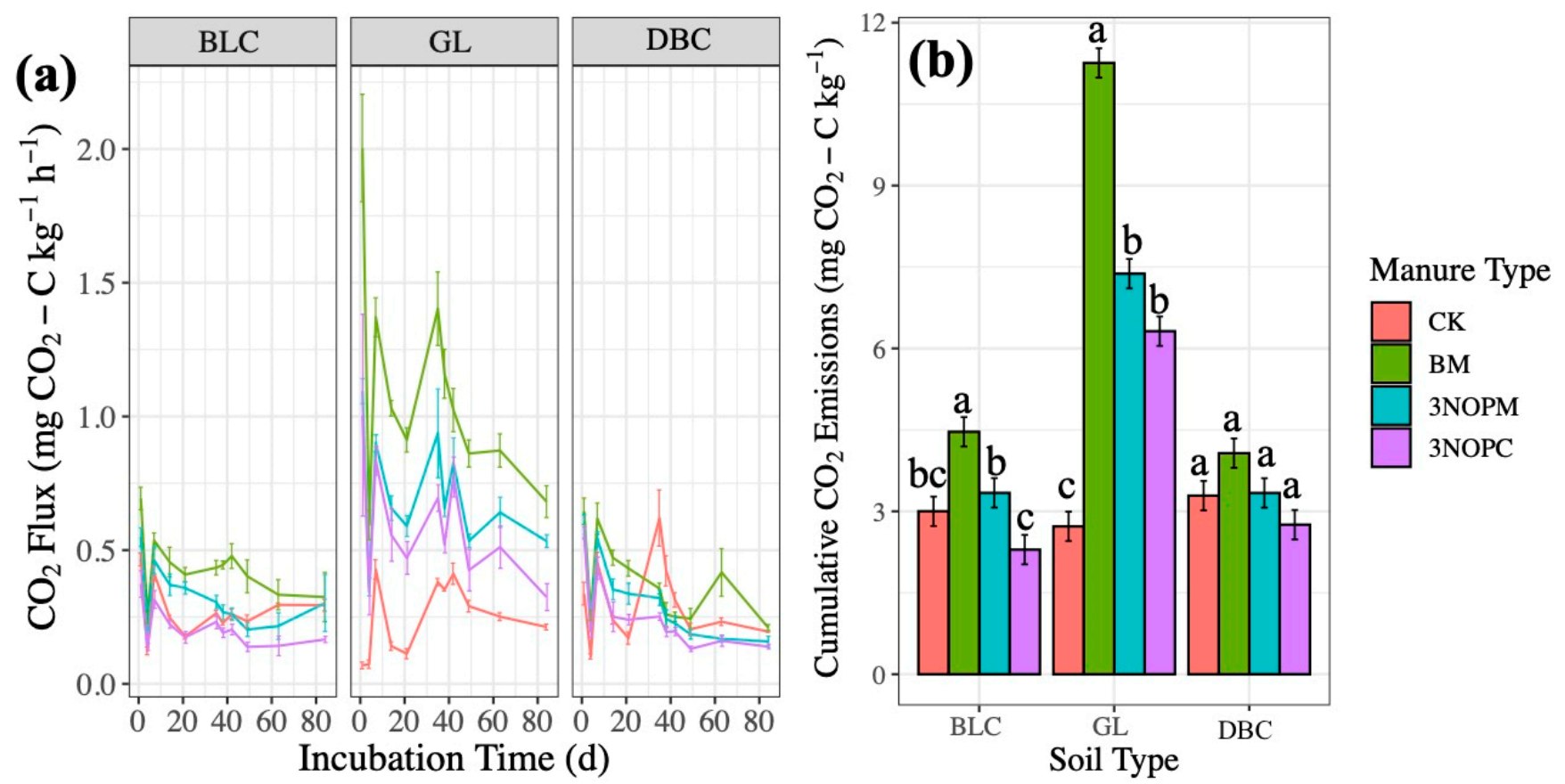

Figure 1. Effects of manure type on $\mathrm{CO}_{2}$ emissions (a) over time by soil type and (b) cumulatively by soil type in a laboratory incubation experiment. Soil type: BLC, Black Chernozem; GL, Gray Luvisol; DBC, Dark Brown Chernozem. Manure type: CK, control with no amendments; BM, barley-based manure; 3-NOPM, manure from cows fed 3-NOP supplement; 3-NOPC, composted manure from cows fed 3-NOP supplements. Treatments that do not share the same letter are significantly different from each other. Error bars indicate standard errors of the means $(n=4)$.

On day 35, there was another peak in $\mathrm{CO}_{2}$ emissions, a result of the change from 60 to $80 \%$ WFPS (Figure 1a), suggesting that the increased water availability enhanced the microbial activities for a period of time because of the increased availability of easily decomposable material [2,33]. Similar to Hadas and Portnoy [19] and Hao et al. [34], 
the $\mathrm{CO}_{2}$ emissions declined over time (Figure 1a) due to the decreased organic matter availability and sustained reduction in soil aeration.

The cumulative $\mathrm{CO}_{2}$ emissions were significantly lower in the 3NOPM-amended soils than in the BM-amended soils across Black Chernozem and Gray Luvisol soil types $(p<0.001$, Figure $1 \mathrm{~b})$, while there was no significant effect of manure type in the Dark Brown Chernozem. Composting (3-NOPC) further significantly reduced cumulative $\mathrm{CO}_{2}$ emissions as compared with the non-composted manure from cattle fed with 3-NOP in the Black Chernozem (Figure 1b).

During the composting process, many hydrophobic nonpolar biomolecules are transformed into hydrophilic, soluble molecules, allowing for greater microbial activity $[6,18,20]$, and the aerobic, rather than anaerobic, decomposition of manure is promoted [20]. The composting process thus results in highly recalcitrant organic matter that is resistant to microbial breakdown [24]. The lower C concentration in 3-NOPC than in 3-NOPM $(p<0.001$, Table 1) likely reduced the microbial activity and $\mathrm{CO}_{2}$ emissions upon their application. The manure and soil types interacted to affect the cumulative $\mathrm{CO}_{2}$ emissions for amended treatments $(p<0.001$, Table 2$)$.

Table 2. Results of two-way ANOVAs ( $p$-values) testing the effects of soil type, manure type, and their interactions on the cumulative greenhouse gas (GHG) emissions $(n=4)$.

\begin{tabular}{cccc}
\hline Source of Variation & Soil Type (S) & Manure Type (M) & $\mathbf{S} \times \mathbf{M}$ \\
\hline $\mathrm{CO}_{2}$ emissions & $<0.001$ & $<0.001$ & $<0.001$ \\
$\mathrm{~N}_{2} \mathrm{O}$ emissions & $<0.001$ & $<0.001$ & $<0.001$ \\
$\mathrm{CH}_{4}$ emissions & $<0.001$ & 0.368 & 0.265 \\
$\mathrm{GHG}\left(\mathrm{CO}_{2}\right.$ eq $)$ & $<0.001$ & $<0.001$ & $<0.001$ \\
\hline
\end{tabular}

The $\mathrm{CO}_{2}$ emission rates were greater in the Gray Luvisol than in Black and Dark Brown Chernozems, and the difference among the soils were greater when BM than when 3-BNOPM and 3-NOPC were applied ( $p<0.001$, Table 2; Figure 1b). The $\mathrm{pH}$ was significantly lower in the Gray Luvisol $(3.91, p<0.001)$ and was greatest in $\mathrm{BM}>3$-NOPM $>3$-NOPC $(p<0.001)$ (Table 1$)$. The cumulative $\mathrm{CO}_{2}$ emission rates were highly correlated with $\mathrm{pH}(p<0.01$, Table 3$)$, consistent with Li et al. [6], suggesting that soil $\mathrm{pH}$ played a major role in the interaction effects between manure and soil types on the cumulative $\mathrm{CO}_{2}$ emissions.

Table 3. Pearson's correlation coefficients for the correlation among cumulative $\mathrm{CO}_{2}, \mathrm{~N}_{2} \mathrm{O}$, and $\mathrm{CH}_{4}$ emissions and initial soil properties $(n=12)$.

\begin{tabular}{cccccccc}
\hline Variable & $\mathbf{p H}$ & Total N & Organic $\mathbf{C}$ & $\mathbf{C} / \mathbf{N}$ & $\mathbf{N H}_{4}{ }^{-}-\mathbf{N}$ & $\mathbf{N O}_{3}{ }^{-}-\mathbf{N}$ & $\mathbf{A N}$ \\
\hline $\mathrm{CO}_{2}$ & $-0.60^{* *}$ & -0.29 & -0.17 & 0.07 & $0.59^{* *}$ & $0.37^{*}$ & $0.38^{*}$ \\
$\mathrm{~N}_{2} \mathrm{O}$ & $-0.61^{* *}$ & -0.27 & -0.15 & 0.06 & $0.59^{* *}$ & $0.35^{*}$ & $0.36^{* *}$ \\
$\mathrm{CH}_{4}$ & -0.04 & -0.25 & -0.15 & $0.44^{* *}$ & -0.03 & 0.07 & 0.06 \\
\hline
\end{tabular}

Abbreviations: $\mathrm{C} / \mathrm{N}$, soil carbon to nitrogen ratio; $\mathrm{AN}$, available nitrogen; total $\mathrm{N}$, total nitrogen. Significance: ${ }^{*} p<0.05 ;{ }^{* *} p<0.01$.

\section{2. $\mathrm{N}_{2} \mathrm{O}$ Emissions}

The highest $\mathrm{N}_{2} \mathrm{O}$ emissions from the different soils and manure types occurred on day one (Figure 2a). The initial $\mathrm{N}_{2} \mathrm{O}$ emissions in amended treatments likely came from nitrification, which occurs under aerobic conditions when WFPS was maintained at $60 \%[2,21,35]$. The emission of nitrous oxide continued until day 42 for the Gray Luvisol and Dark Brown Chernozem soils (Figure 2a), partly related to the change in the soil water content from 60 to $80 \%$ WFPS after 14 days from the initiation of the treatments, allowing denitrification to occur and to contribute to the extended $\mathrm{N}_{2} \mathrm{O}$ emissions [33]. 

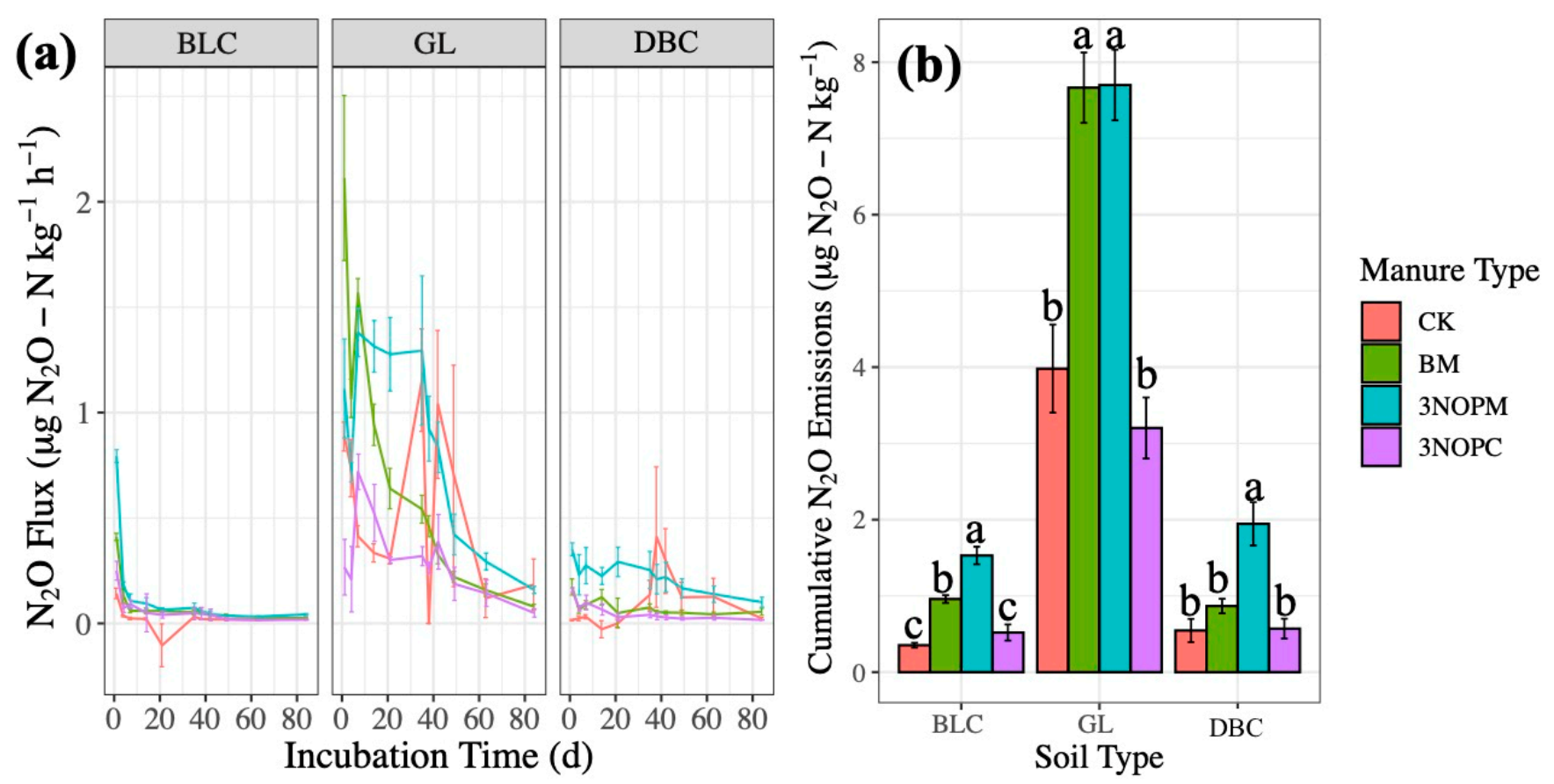

Figure 2. Effects of manure type on $\mathrm{N}_{2} \mathrm{O}$ emissions (a) over time by soil type and (b) cumulatively by soil type in a laboratory incubation experiment. Soil type: BLC, Black Chernozem; GL, Gray Luvisol; DBC, Dark Brown Chernozem. Manure type: CK, control with no amendments; BM, barley-based manure; 3-NOPM, manure from cows fed 3-NOP supplement; 3-NOPC, composted manure from cows fed 3-NOP supplements. Treatments that do not share the same letter are significantly different from each other. Error bars indicate standard errors of the means $(n=4)$.

Under aerobic conditions, $\mathrm{N}_{2} \mathrm{O}$ emissions would only last for the first a few weeks, as observed by Li et al. [6] and Bhandral et al. [36]. Denitrification occurs under anaerobic conditions ( $>60 \%$ WFPS), when the lack of $\mathrm{O}_{2}$ requires denitrifying microorganisms to utilize $\mathrm{NO}_{3}{ }^{-}-\mathrm{N}$ instead of $\mathrm{O}_{2}$ as an electron acceptor $[2,37,38]$. The nitrous oxide emissions then decreased considerably from day 49 until the end of the incubation.

The interaction of soil type and manure type was significant for the $\mathrm{N}_{2} \mathrm{O}$ emissions $(p<0.001$, Table 2) because of the complex interrelationships among soil and manure properties (Table 1). Higher $\mathrm{C}$ concentrations (BM and the two Chernozemic soils) can enhance denitrification by directly providing donor electrons and stimulating $\mathrm{O}_{2}$ consumption, and lower levels of $\mathrm{NH}_{4}{ }^{+}-\mathrm{N}$ (in the Chernozemic soils) reduce microbial assimilatory $\mathrm{NO}_{3}{ }^{-}-\mathrm{N}$ reduction $[24,35]$.

The nitrous oxide emissions were significantly higher from the 3-NOPM treatment than the other three treatments on Black Chernozem and Dark Brown Chernozem soils, but not on the Gray Luvisol, where the $\mathrm{N}_{2} \mathrm{O}$ emissions were similar between the 3-NOPM and BM treatments (Figure 2b). There was significantly greater $\mathrm{NO}_{3}{ }^{-}-\mathrm{N}$ in 3-NOPM and 3-NOPC than in BM $\left(p<0.001\right.$, Table 1); the higher $\mathrm{NO}_{3}{ }^{-}$- $\mathrm{N}$ availability increased the $\mathrm{N}_{2} \mathrm{O}$ emission rates (Table 3 ) from anaerobic processes [33-35].

Soil type also significantly affected the $\mathrm{N}_{2} \mathrm{O}$ emissions $(p<0.001$, Table 2$)$, with the Chernozemic soils having lower cumulative $\mathrm{N}_{2} \mathrm{O}$ emissions (Figure $2 b$ ). The Gray Luvisol soils had significantly higher available $\mathrm{N}$ than the Black and Dark Brown Chernozem soils for all treatments $(p<0.01$, Table 1$)$, which resulted in greater $\mathrm{N}_{2} \mathrm{O}$ emissions [2], and $\mathrm{N}_{2} \mathrm{O}$ emissions were affected by soil $\mathrm{pH}(p<0.001)$. The neutral-basic Black and Dark Brown Chernozem soils started with lower $\mathrm{NH}_{4}{ }^{+}-\mathrm{N}$ (Table 1), limiting the potential nitrification rates for $\mathrm{NO}_{3}{ }^{-}-\mathrm{N}$ production.

\section{3. $\mathrm{CH}_{4}$ Emissions}

Most $\mathrm{CH}_{4}$ emissions occurred before day 35 across all treatments (Figure $3 \mathrm{a}, \mathrm{b}$ ), similar to the $\sim 50 \%$ of the total $\mathrm{CH}_{4}$ fluxes occurring during the first 28 days of a laboratory 
incubation experiment reported by Hao et al. [34]. Methane emissions increased when the total $\mathrm{C}$ increases in our study $(p<0.01$, Table 3$)$, as organic materials with a high $\mathrm{C} / \mathrm{N}$ ratio are rich in labile $C$ and methanogenic potential and organic matter content are positively related [34,39]. Methane emissions are produced when organic matter is mineralized in anaerobic environments with a low redox potential [2,39].
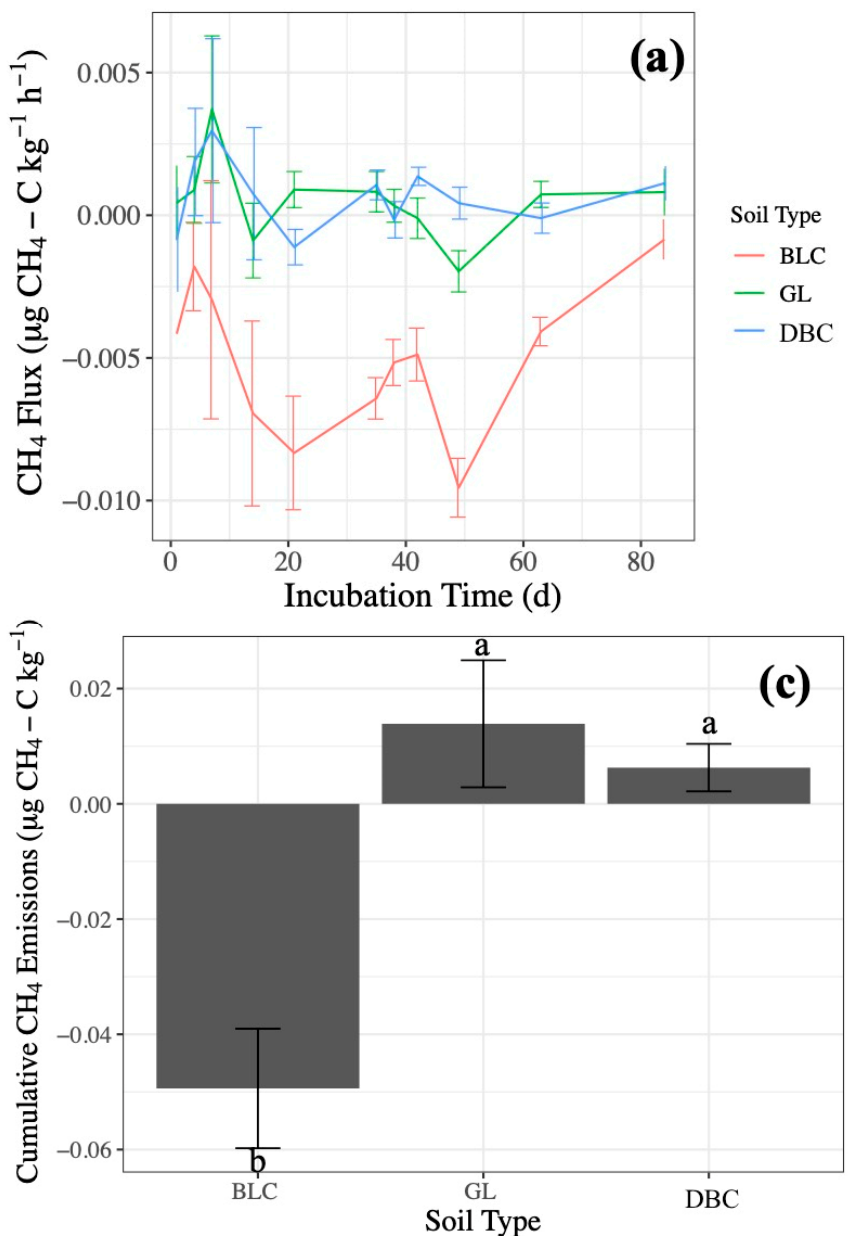
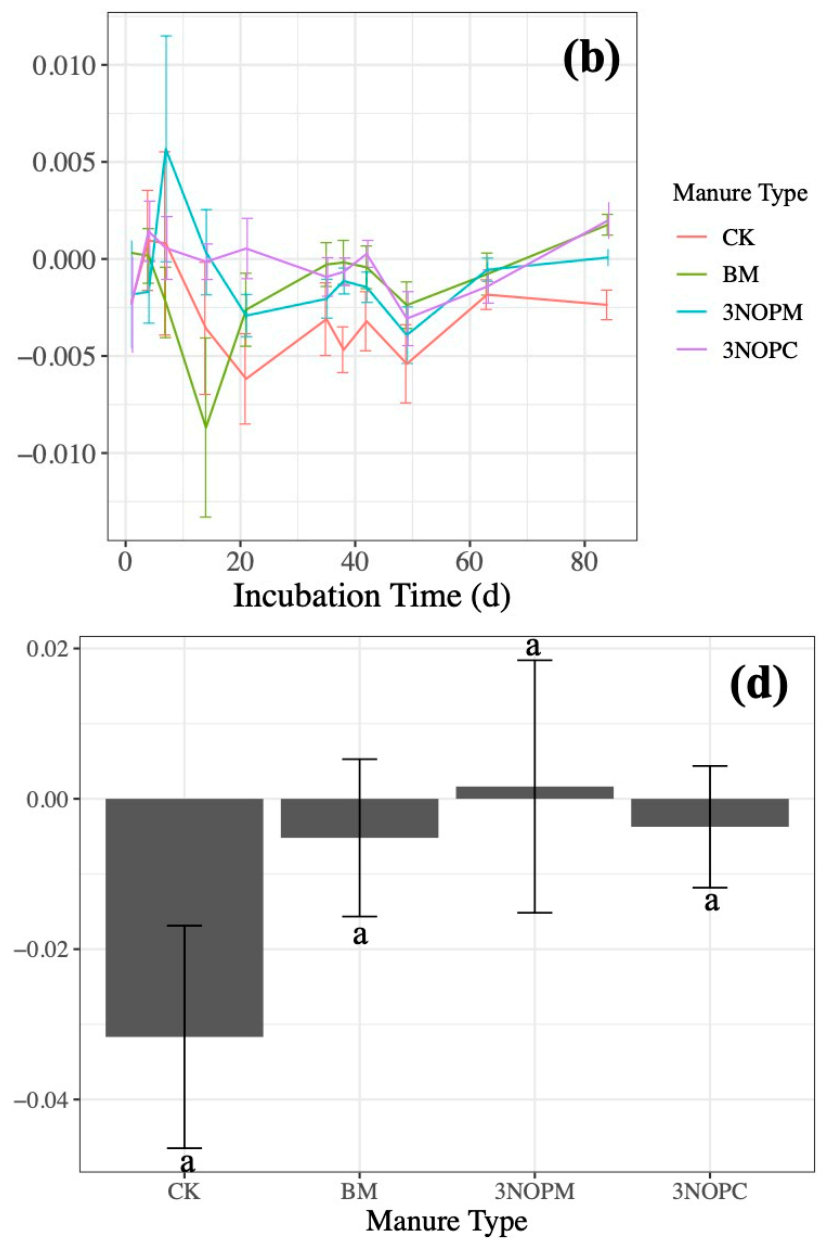

Figure 3. Effects of (a) soil type on $\mathrm{CH}_{4}$ emissions over time, (b) manure type on $\mathrm{CH}_{4}$ emissions over time, (c) soil type on cumulative $\mathrm{CH}_{4}$ emissions, and (d) manure type on cumulative $\mathrm{CH}_{4}$ emissions in a laboratory incubation experiment. Soil type: BLC, Black Chernozem; GL, Gray Luvisol; DBC, Dark Brown Chernozem. Manure type: CK, control with no amendments; BM, barley-based manure; 3-NOPM, manure from cows fed 3-NOP supplement; 3-NOPC, composted manure from cows fed 3-NOP supplements. Treatments that do not share the same letter are significantly different from each other. Error bars indicate standard errors of the means $(n=4)$.

The addition of manure can temporarily create an anaerobic zone in the soil, enhancing the initial $\mathrm{CH}_{4}$ production [8,34]. After day 21, most of the $\mathrm{CH}_{4}$ emissions were negative (Figure $3 \mathrm{a}, \mathrm{b}$ ), indicating that the manure and soil had become $\mathrm{CH}_{4}$ sinks, with the sum of $\mathrm{CH}_{4}$ production by methanogenic bacteria and consumption by methanotrophic bacteria being negative $[27,40,41]$. The $\mathrm{CH}_{4}$ emissions may decline as nutrients from the manure amendment become depleted [37].

Only soil type had a significant impact on $\mathrm{CH}_{4}$ emissions $(p<0.001$, Table 2$)$. The Black Chernozem had negative $\mathrm{CH}_{4}$ emissions under all amendment types, indicating that the Black Chernozem served as a $\mathrm{CH}_{4}$ sink regardless of manure application $(p<0.001$, Figure $3 c)$. The Black Chernozem had the lowest $C / N(p=0.001$, Table 1$)$, and the low $C$ availability might limit microbial production of $\mathrm{CH}_{4}[22,36,40]$. The finer soil texture of the Dark Brown Chernozem and Gray Luvisol (clay loam) than the Black Chernozem (sandy 
loam) might have caused the higher $\mathrm{CH}_{4}$ emissions due to anaerobic conditions created in the finer-textured soils [39].

\subsection{Total GHG Emissions}

The impact of $\mathrm{N}_{2} \mathrm{O}$ emissions is magnitudes greater than $\mathrm{CH}_{4}$ on the cumulative anthropogenic GHG emissions $\left(\mathrm{N}_{2} \mathrm{O}\right.$ and $\mathrm{CH}_{4}$ as $\mathrm{CO}_{2}$-equivalents) (Figures $2 \mathrm{~b}$ and $3 \mathrm{c}, \mathrm{d}$ ). Positive and negative fluxes up until day 35 from Black and Dark Brown Chernozemic soils and positive GHG emissions up until day 60 from the Gray Luvisolic soil (Figure 4a) indicate prolonged microbial respiration. Substantially greater cumulative total GHG emissions from the Gray Luvisol highlight the importance of considering different soil types and their potential interaction with manure amendments (Figure $4 b$ ). The cumulative anthropogenic GHG emissions from the Black Chernozemic soil amended with 3-NOPM were significantly higher than for both BM and CK amendments, while the GHG emissions from 3-NOPC amendments were similar to or significantly lower than for BM and CK amendments across all soil types (Figure 4 b). Relative to 3-NOPM, 3-NOPC significantly reduced total GHG emissions across all soil types, likely due to the composting process converting easily degradable $\mathrm{C}$ and $\mathrm{N}$ into less biologically active forms [24,38].
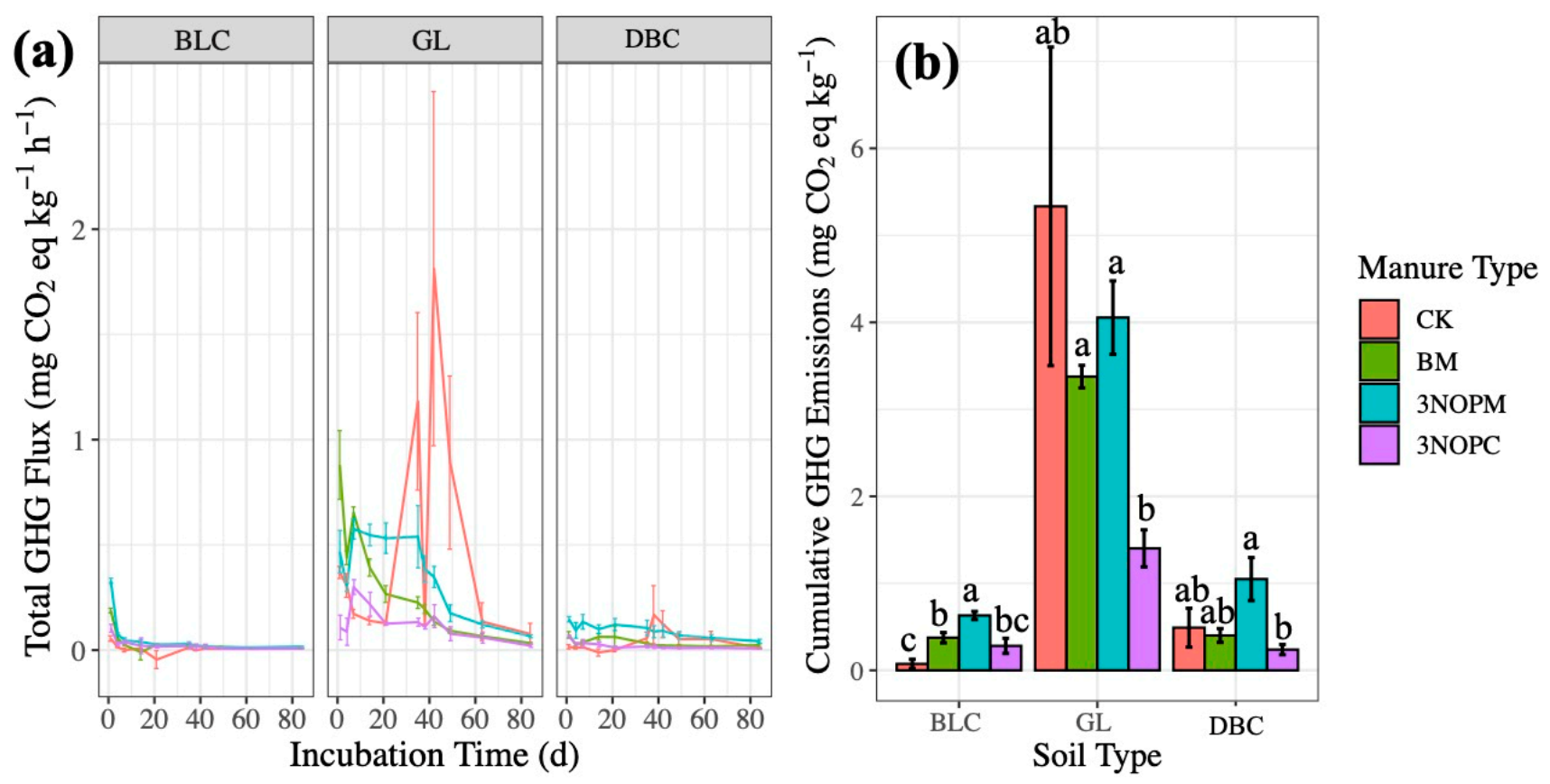

Figure 4. Effects of manure type on anthropogenic GHG emissions $\left(\mathrm{N}_{2} \mathrm{O}\right.$ and $\mathrm{CH}_{4}$ as $\mathrm{CO}_{2}$-equivalents) (a) over time by soil type and (b) cumulatively by soil type in a laboratory incubation experiment. Soil type: BLC, Black Chernozem; GL, Gray Luvisol; DBC, Dark Brown Chernozem. Manure type: CK, control with no amendments; BM, barley-based manure; 3-NOPM, manure from cows fed 3-NOP supplement; 3-NOPC, composted manure from cows fed 3-NOP supplements. Treatments that do not share the same letter are significantly different from each other. Error bars indicate standard errors of the means $(n=4)$.

\section{Conclusions}

Our results show that both cattle diet and manure management approaches affect GHG emissions from soils amended with manure. In this first look at the potential effect of the next stage in the life cycle of 3-NOP on GHG emissions, we found that GHG emissions resulting from soil amended with 3-NOPM are dependent on soil type (e.g., texture). For the coarse-textured Black Chernozemic soil (which had the lowest total GHG emissions across all soil types), the 3-NOPM amendment resulted in greater cumulative anthropogenic GHG emissions compared to both BM and CK. The composting of 3-NOPM prior to amendment 
reduced GHG emissions across all soil types. However, we caution that the composting process also releases GHGs which can be similar or even greater in magnitude than those released following soil amendment.

Further research related to the effect of soil properties, as well as field studies, are needed to provide farmers with best management practices related to the use of manure as a soil amendment from cattle fed a diet supplemented with 3-NOP. In particular, we recommend caution in applying the results of this incubation experiment to the field, which would have different conditions (e.g., growth of plants). Nonetheless, this research provides an important contribution by showing that the GHG emissions resulting from soil amended with manure from cattle fed a 3-NOP-supplemented diet potentially can be mitigated by applying the manure to certain types of soil (e.g., fine-textured soil) or by composting the manure prior to application.

Author Contributions: Conceptualization and methodology: X.H. and S.X.C.; investigation: T.L.W.; writing and editing: T.L.W., C.D.G., X.H., K.A.B. and S.X.C.; resources and supervision, X.H. and S.X.C. All authors have read and agreed to the published version of the manuscript.

Funding: This study was financially supported by Agriculture and Agri-Food Canada (AAFC), Alberta Livestock and Meat Agency (ALMA), Natural Science and Engineering Research Council of Canada (NSERC), and the University of Alberta.

Institutional Review Board Statement: Not applicable.

Informed Consent Statement: Not applicable.

Data Availability Statement: Data is contained within the article.

Conflicts of Interest: The authors declare no conflict of interest.

\section{References}

1. de Vries, M.; de Boer, I.J.M. Comparing environmental impacts for livestock products: A review of life cycle assessments. Livest. Sci. 2010, 128, 1-11. [CrossRef]

2. Smith, K.A.; Ball, T.; Conen, F.; Dobbie, K.E.; Massheder, J.; Rey, A. Exchange of greenhouse gases between soil and atmosphere: Interactions of soil physical factors and biological processes. Eur. J. Soil Sci. 2003, 54, 779-791. [CrossRef]

3. IPCC. Change 2014: Synthesis Report. Contribution of Working Groups I, II and III to the Fifth Assessment Report of the Intergovernmental Panel on Climate Change; IPCC: Geneva, Switzerland, 2014; ISBN 92-9169-113-5.

4. Lopes, J.C.; de Matos, L.F.; Harper, M.T.; Giallongo, F.; Oh, J.; Gruen, D.; Ono, S.; Kindermann, M.; Duval, S.; Hristov, A.N. Effect of 3-nitrooxypropanol on methane and hydrogen emissions, methane isotopic signature, and ruminal fermentation in dairy cows. J. Dairy Sci. 2016, 99, 5335-5344. [CrossRef] [PubMed]

5. Haisan, J.; Sun, Y.; Guan, L.L.; Beauchemin, K.A.; Iwaasa, A.; Duval, S.; Barreda, D.R.; Oba, M. The effects of feeding 3nitrooxypropanol on methane emissions and productivity of Holstein cows in mid lactation. J. Dairy Sci. 2014, 97, 3110-3119. [CrossRef]

6. Li, P.; Lang, M.; Li, C.; Hao, X. Nitrous oxide and carbon dioxide emissions from soils amended with compost and manure from cattle fed diets containing wheat dried distillers' grains with solubles. Can. J. Soil Sci. 2016, 97, 522-531. [CrossRef]

7. Reeve, J.R.; Endelman, J.B.; Miller, B.E.; Hole, D.J. Residual effects of compost on soil quality and dryland wheat yield sixteen years after compost application. Soil Sci. Soc. Am. J. 2012, 76, 278. [CrossRef]

8. Hütsch, B.W.; Webster, C.P.; Powlwn, D.S. Long-term effects of nitrogen on methane oxidation in soil of the wheat experiment. Soil Sci. 1993, 25, 1307-1315.

9. Reynolds, C.K.; Humphries, D.J.; Kirton, P.; Kindermann, M.; Duval, S.; Steinberg, W. Effects of 3-nitrooxypropanol on methane emission, digestion, and energy and nitrogen balance of lactating dairy cows. J. Dairy Sci. 2014, 97, 3777-3789. [CrossRef]

10. Vyas, D.; Alemu, A.W.; McGinn, S.M.; Duval, S.M.; Kindermann, M.; Beauchemin, K.A. The combined effects of supplementing monensin and 3-nitrooxypropanol on methane emissions, growth rate, and feed conversion efficiency in beef cattle fed high-forage and high-grain diets. J. Anim. Sci. 2018, 96, 2923-2938. [CrossRef]

11. Duin, E.C.; Wagner, T.; Shima, S.; Prakash, D.; Cronin, B.; Yáñez-Ruiz, D.R.; Duval, S.; Rümbeli, R.; Stemmler, R.T.; Thauer, R.K.; et al. Mode of action uncovered for the specific reduction of methane emissions from ruminants by the small molecule 3-nitrooxypropanol. Proc. Natl. Acad. Sci. USA 2016, 113, 6172-6177. [CrossRef]

12. Romero-Perez, A.; Okine, E.K.; McGinn, S.M.; Guan, L.L.; Oba, M.; Duval, S.M.; Kindermann, M.; Beauchemin, K.A. The potential of 3-nitrooxypropanol to lower enteric methane emissions from beef cattle. J. Anim. Sci. 2014, 92, 4682-4693. [CrossRef]

13. Jayasundara, S.; Ranga Niroshan Appuhamy, J.A.D.; Kebreab, E.; Wagner-Riddle, C. Methane and nitrous oxide emissions from Canadian dairy farms and mitigation options: An updated review. Can. J. Anim. Sci. 2016, 96, 306-331. [CrossRef] 
14. Romero-Perez, A.; Okine, E.K.; McGinn, S.M.; Guan, L.L.; Oba, M.; Duval, S.M.; Kindermann, M.; Beauchemin, K.A. Sustained reduction in methane production from long-term addition of 3-nitrooxypropanol to a beef cattle diet. J. Anim. Sci. 2015, 93, 1780-1791. [CrossRef] [PubMed]

15. Larney, F.J.; Hao, X. A review of composting as a management alternative for beef cattle feedlot manure in southern Alberta, Canada. Bioresour. Technol. 2007, 98, 3221-3227. [CrossRef]

16. Schlegel, A.J. Effect of composted manure on soil chemical properties and nitrogen use by grain sorghum. J. Prod. Agric. 1992, 5, 153-157. [CrossRef]

17. Sadeghpour, A.; Ketterings, Q.M.; Vermeylen, F.; Godwin, G.S.; Czymmek, K.J. Soil properties under nitrogen- vs. phosphorusbased manure and compost management of corn. Soil Sci. Soc. Am. J. 2016, 80, 185-195. [CrossRef]

18. Ros, M.; Klammer, S.; Knapp, B.; Aichberger, K.; Insam, H. Long-term effects of compost amendment of soil on functional and structural diversity and microbial activity. Soil Use Manag. 2006, 22, 209-218. [CrossRef]

19. Hadas, A.; Portnoy, R. Nitrogen and carbon mineralization rates of composted manures incubated in soil. J. Environ. Qual. 1994, 23, 1184-1189. [CrossRef]

20. Hao, X.; Chang, C.; Larney, F.J.; Travis, G.R. Greenhouse gas emissions during cattle feedlot manure composting. J. Environ. Qual. 2001, 30, 376-386. [CrossRef] [PubMed]

21. Paul, E.A. Soil Microbiology, Ecology and Biochemistry; Elsevier: Amsterdam, The Netherlands, 2015; ISBN 9780124159556.

22. Wang, X.; Yang, G.; Feng, Y.; Ren, G.; Han, X. Optimizing feeding composition and carbon-nitrogen ratios for improved methane yield during anaerobic co-digestion of dairy, chicken manure and wheat straw. Bioresour. Technol. 2012, 120, 78-83. [CrossRef] [PubMed]

23. Li, P.; Lang, M.; Li, C.; Thomas, B.W.; Hao, X. Nutrient leaching from soil amended with manure and compost from cattle fed diets containing wheat dried distillers' grains with solubles. Water Air Soil Pollut. 2016, 227, 393. [CrossRef]

24. Kaiser, M.; Kleber, M.; Berhe, A.A. How air-drying and rewetting modify soil organic matter characteristics: An assessment to improve data interpretation and inference. Soil Biol. Biochem. 2015, 80, 324-340. [CrossRef]

25. Franzluebbers, A.J. Microbial activity in response to water-filled pore space of variably eroded southern Piedmont soils. Appl. Soil Ecol. 1999, 11, 91-101. [CrossRef]

26. Murphy, D.; Recous, S.; Stockdale, E.; Fillery, I.R.; Jensen, L.; Hatch, D.; Goulding, K.W. Gross nitrogen fluxes in soi: Theory, measurement and application of $15 \mathrm{~N}$ pool dilution techniques. Adv. Agron. 2003, 79, 69-118.

27. Gregorich, E.; Rochette, P.; VandenBygaart, A.; Angers, D. Greenhouse gas contributions of agricultural soils and potential mitigation practices in Eastern Canada. Soil Tillage Res. 2005, 83, 53-72. [CrossRef]

28. Moraghan, J.T.; Buresh, R. Correction for dissolved nitrous oxide in nitrogen studies. Soil Sci. Soc. Am. J. 1977, 41, 1201-1202. [CrossRef]

29. Ramnarine, R.; Voroney, R.P.; Wagner-Riddle, C.; Dunfield, K.E. Carbonate removal by acid fumigation for measuring the $\delta^{13} \mathrm{C}$ of soil organic carbon. Can. J. Soil Sci. 2011, 91, 247-250. [CrossRef]

30. Premrov, A.; Cummins, T.; Byrne, K.A. Bulk-density modelling using optimal power-transformation of measured physical and chemical soil parameters. Geoderma 2018, 314, 205-220. [CrossRef]

31. Norman, A.G.; Bremner, J.M. Inorganic Forms of Nitrogen. In Methods of Soil Analysis. Part 2: Chemical and Microbiological Properties; Soil Science Society of America and American Society of Agronomy: Madison, WI, USA, 1965; pp. 672-676. ISBN 978-0-89118-204-7.

32. Miranda, K.M.; Espey, M.G.; Wink, D.A. A Rapid, Simple Spectrophotometric Method for Simultaneous Detection of Nitrate and Nitrite. Nitric Oxide 2001, 5, 62-71. [CrossRef]

33. Logan, M. Biostatistical Design and Analysis Using R; John Wiley \& Sons: Hoboken, NJ, USA, 2010.

34. Ruser, R.; Flessa, H.; Russow, R.; Schmidt, G.; Buegger, F.; Munch, J.C. Emission of $\mathrm{N}_{2} \mathrm{O} \mathrm{N}_{2}$ and $\mathrm{CO}_{2}$ from soil fertilized with nitrate: Effect of compaction, soil moisture and rewetting. Soil Biol. Biochem. 2006, 38, 263-274. [CrossRef]

35. Paustian, K.; Parton, W.J.; Persson, J. Modeling soil organic matter in organic-amended and nitrogen-fertilized long-term plots. Soil Sci. Soc. Am. J. 1992, 56, 476-488. [CrossRef]

36. Hao, X.; Chang, C.; Larney, F.J. Carbon, nitrogen balances and greenhouse gas emission during cattle feedlot manure composting. J. Environ. Qual. 2004, 33, 37-44. [CrossRef]

37. Bremner, J.M.; Shaw, K. Denitrification in soil. II. Factors affecting denitrification. J. Agric. Sci. 1958, 51, 40-52. [CrossRef]

38. Datta, M.; Jha, P.; Arumbaka, S. Effects of nitrate supplementation on nutrition, performance and methane mitigation in ruminants: A review. Int. J. Livest. Res. 2017, 7, 19-29. [CrossRef]

39. Bhandral, R.; Bolan, N.S.; Saggar, S.; Hedley, M.J. Nitrogen transformation and nitrous oxide emissions from various types of farm effluents. Nutr. Cycl. Agroecosyst. 2007, 79, 193-208. [CrossRef]

40. Le Mer, J.; Roger, P. Production, oxidation, emission and consumption of methane by soils: A review. Eur. J. Soil Biol. 2001, 37, 25-50. [CrossRef]

41. Mor, S.; De Visscher, A.; Ravindra, K.; Dahiya, R.P.; Chandra, A.; Van Cleemput, O. Induction of enhanced methane oxidation in compost: Temperature and moisture response. Waste Manag. 2006, 26, 381-388. [CrossRef] 